\title{
КОНЦЕСИВНИТЕ НЕИНТЕГРИРАНИ КОНСТРУКЦИИ ВО МАКЕДОНСКИОТ ЈАЗИК
}

Бојан Петревски

Универзитет „Св. Кирил и Методиј“, Скопје

bojan_petrevski@yahoo.com

Во трудот се разгледуваат конструкциите со концесивно значење конституирани од (глаголски и квалификативни) придавки, именки и глаголски прилози што се издвоени во прозодиската структура на исказот. Интересот се сосредоточува на неколку аспекти: информацискиот карактер и позицијата на конструкциите, од една страна, и синтаксичката функција и статусот на планот на опозицијата йознайо - ново (т.е. идентификуваноста и неидентификуваноста) на носителите (референтите), од друга страна. Примерите се ексцерпирани од повеќе автори, главно од уметничколитературниот функционален стил.

Клучни зборови: концесија, неинтегрирана конструкција, информација, референт, синтаксичка функција 


\title{
CONCESSIVE NON-IMBEDDED CONSTRUCTIONS IN MACEDONIAN
}

\author{
Bojan Petrevski \\ Ss Cyril and Methodius University, Skopje \\ bojan_petrevski@yahoo.com
}

The paper discusses the concessive constructions consisting of (verbal and qualifying) adjectives, nouns and verbal adverbs detached from the prosodic structure of the utterance. This paper focuses on several properties of these constructions: the information character and the position of the constructions, on the one hand, and the syntactic functions of the referents and their status regarding the opposition given vs. new information, on the other hand. The analysis is carried out on examples collected from literary works by several Macedonian writers.

Key words: concession, non-embedded construction, information, referent, syntactic function 


\section{Вовед}

Во овој труд се разгледуваат алтернативните формализации со концесивно значење, т.е. конструкциите со придавки (глаголски и квалификативни), глаголски прилози и именки. Притоа, предмет на истражувањето се конструкциите што се нецелосно вклопени, неинтегрирани во прозодиската структура на исказот. Во таа смисла, тие се дел од неинтегрираните конструкции во смислата во која ги разгледува Комбет (Combettes 1998) во францускиот јазик. Освен што се прозодиски неинтегрирани:

- тие се слободни во поглед на позицијата, т.е. може да бидат поставени и во зоната лево и во зоната десно од предикатот;

- носители се на секундарна, редуцирана предикативна структура

- се однесуваат на елемент на примарната предикација.

Според тоа, врз материјал од неколку автори од уметничко-литературниот функционален стил, ќе стане збор за конструкциите од типот на: Завиgно искусен, йој (сейак) найрави йочетиничка грешка; Зуобиен со завияно

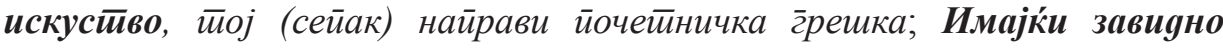
искустиво, йој (сейак) найрави йочетиничка грешка; Искусен човек, тиој (сейак) найрави йочетиничка гррешка, кои се конкурентни со сложените конструкции: Иако е завияно искусен, йој (сейак) найрави йочетиничка грешка; Иако е зуобиен со завияно искусииво, йој (сейак) найрави йочейничка гррешка; Иако има завияно искусивво, йој (сейак) найрави йочетиничка гррешка, кои (сложените конструкции) во македонистичката средина се разгледани во трудовите на Цветковски (1982), ШоклароваЉоровска (1996), Геговски (1996), Тополињска (1997: 77-80), МиноваЃуркова (2000: 287-290).

Целта на трудот е да покаже како се однесуваат конструкциите на неколку плана: информациската хиерархија, линеаризацијата, реченичните функции и (не)идентификуваноста на референтите. Во таа смисла, клучни се следниве прашања: на какви информации се однесуваат во однос на остатокот од исказот, кои позиции ги заземаат во него и кон кои референти гравитираат во поглед на нивната реченична функција и релација со претходниот контекст. Најпосле, ќе биде разгледано и прашањето од кои зборовни класи се регрутираат најчесто. Резултатите ќе покажат под кои услови се прибегнува кон формализација на концесивните значења како неинтегрирани конструкции. 


\section{1 Информацискиот карактер на конструкциите}

\section{1 Општа информациска особеност}

Допусните неинтегрирани конструкции споделуваат уште една, клучна карактеристика на неинтегрираните конструкции воопшто, која е од информациски карактер. Нивната прозодиска издвоеност произлегува од тоа што посочуваат информациски секундарни содржини, кои котираат пониско од другиот дел на исказот (комуникациското јадро, т.е. примарната тема и примарната рема), па не може да се разгледуваат ни како тема ни како рема во вистинска смисла (Combettes 1998). Во таа смисла, во исказот Завияно искусен, йој (сейак) найрави йочейничка грреика, тема е йој, преод - найрави, а рема - иочейничка гррешка (или, уште попрецизно,

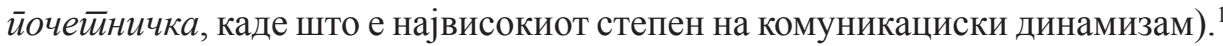
Од друга страна, според критериумите на Комбет (Combettes 1998: 66-68), содржината на неинтегрираната конструкција (завияно искусен) може да се разгледува или како секундарна тема (ако е посочена во претходниот контекст) или како секундарна рема (ако е сосема нова, непозната за соговорникот / читателот).

Во крајна линија, поради информациската секундарност, неинтегрираните конструкции може и да се изостават, со што ќе се осиромаши информативноста на исказот, но нема да се засегне неговата кохерентност. Таа нивна карактеристика најдобро се согледува во сопоставеност со интегрираните пандани (1), кои функционираат како рема, поради што се задолжителни за кохерентноста на исказот, т.е. не може да се изостават (1a).

(1) Сийе gруг̄и и рабойеа и се оgмораа. Само йој рабойеше неодморен. ('кога работеше, тој беше неодморен' / 'тој работеше, иако не беше одморен')

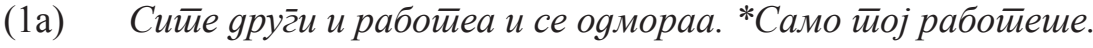

Од друга страна, неинтегрираните конструкции (2) не ја условуваат кохерентноста на исказот, а кога содржината се подразбира од претходниот контекст, и да се изостават, нема да биде засегнат ни информацискиот аспект. Во таа смисла, исказот во (2а) не само што е кохерентен туку не е ни информациски посиромашен од исказот во (2).

1 Терминот комуникациски динамизам се употребува во смислата во која го употребува Фирбас (Firbas 1992), како придонес на јазичните единици за развојот на комуникацијата. 
(2) Не си gаваше оggишка. Неодморен, йој рабоиете и gоgека gругийе се оgмораа. ('иако не беше одморен, тој работеше')

(2а) Не си gаваме оggишка. Тој рабоиееше и доgека gруг̄ииее се оgмораа.

Најпосле, дури и во случаите каде што содржината е сосема нова (неспомената во претходниот контекст), ако е формализирана како неинтегрирана конструкција, авторот ја оценил како информациски секундарна, па и да се изостави, исказот ќе биде информациски осиромашен, но ќе остане кохерентен. На пример, за разлика од исказот во (3), исказот во (3а) е лишен од таа информација (неоgморена), но прифатлив.

(3) Вчера бевме кај баба ми. Неоgморена, (сейак) сиичг̄нала gа зг̄ойви сѐ.

(3а) Вчера бевме кај баба ми. Сйиг̄нала gа зг̄ойви сѐ.

\section{2 Иницијалните наспроти медијалните и финалните конструкции}

Бидејќи неинтергираните конструкции (независно од значењето) посочуваат информациски секундарна содржина, очекувано е што најчесто ја заземаат иницијалната позиција (која е типична за елементите со понизок степен на комуникациски динамизам). Во таа смисла, во расположливиот материјал, од конструкциите во врска со субјектот - вкупно 22 , повеќето - 17, се јавуваат во иницијална позиција (4), (5), (6). ${ }^{2}$

(4) Веќе во гоодини, йобелен, ӣој се gржи ирав како йушка (...) (Конески 1988: 40) ('иако е побелен').

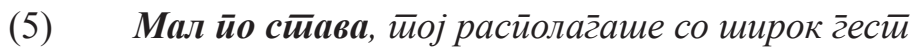
и со имйулсивен барийон. (Конески 1988: 111)

('иако беше мал по става').

(6) Секог̄аш воздржан со своийе gеца, ни gа г̄и г̄али

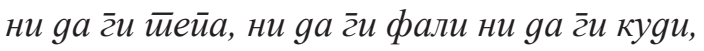

йој не криеше gека најг̄олема наgеж йолаг̄а йокму во нег̄o.

(Солев 1998: 39) ('иако секогаш беше воздржан со своите деца').

2 Комбет (Combettes 1998: 67), Морел (Morel 1996: 89) и Ноели (Noailly 1999: 125) посочуваат иста тенденција во францускиот јазик. 
Медијалните конструкции се јавуваат во два случаја (7), (8).

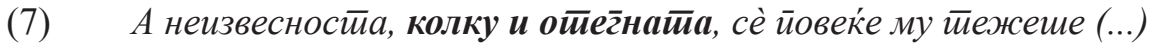

(Солев 1998: 70) ('колку и да беше отегната').

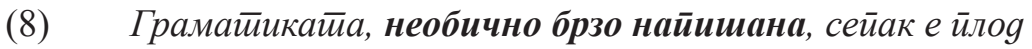

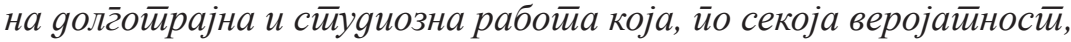
иочнала во сииудискайа 1940/1941 голина.

(Вангелов 2004: 9) ('иако е необично брзо напишана').

Финалните конструкции се јавуваат во три случаи (9), (10), (11).

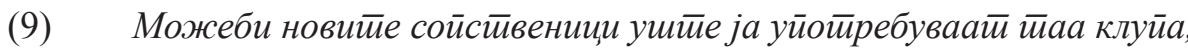
не знаејќи gека е тиаа воен тирофеј на баба Дунавка, исйо како и оној иррешлен. (Конески 1988: 39)

('иако не знаат/без да знаат дека таа е воен триумф на баба Дунавка').

(10) Сег̃a и мојот̄ син краgе, си реков и се насолзив, не сакајќи gа йлачам йреg Генчо. (Бужаровска 2017: 44)

('иако не сакав да плачам пред Генчо').

(11) Тог̄аш оgеше речиси секој gен на факулиеей, иако веќе gийломиран и врабойен (...) (Солев 1998: 56)

('иако веќе беше дипломиран и вработен').

\section{2 Реченичните функции на носителите}

\section{1 Конструкциите во врска со директниот и со индиректниот објект}

Клучно синтаксичко прашање е реченичната функција на носителот на конструкцијата. Во таа смисла, сите претходни примери се дел од тие во кои конструкцијата се однесува на субјектот (кои, како што беше посочено, се јавуваат во 22 случаи). Покрај нив, се изделуваат пет случаи во кои конструкцијата е во врска со друг носител. Така, во (12), (13) и (14) се однесува на директниот објект. 
(12) (...) йа уийе неойворен [индексой] а йаа веќе израяувана, брзаше gа му гоо йокаже на Танас. (Солев 1998: 30) ${ }^{3}$

('иако сѐ уште не беше отворен').

(13) Колку и йомирен, наgежӣа не г̄о найушйаше.

(Солев 1998: 50) ('колку и да беше помирен').

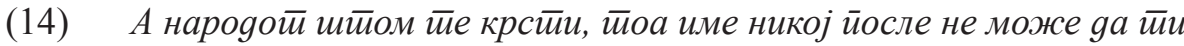
го земе, арно или лошо. (Чинго 1989: 13)

('и да е арно и да е лошо’ / ‘независно од тоа дали е арно или лошо’).

Во (15) конструкцијата се однесува на индиректниот објект.

На Ал, крсииен или некрсииен, бабинойо и народнойо име му остиана за век. (Чинго 1989: 13) ('независно од тоа дали е крстен или некрстен’/‘и да беше крстен и да беше некрстен’).

Во (16) конструкцијата се однесува на постмодификатор.

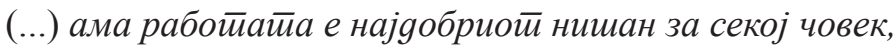
сииар или млаg! (Чинго 1989: 83)

('независно од тоа дали е стар или млад’/и да е стар и да е млад’).

Како што се согледува, во два од случаите со директен објект конструкцијата е иницијална (12), (13), а во еден - финална (14). Во случајот со индиректен објект е медијална (15). Од друга страна, и во случаите со директен и во случајот со индиректен објект носител на конструкцијата е анафорски референт. Во таа смисла, во (12) и (13) е претставен со кратка личнозаменска форма (̌o), а и во (14) и (15) е идентификуван преку тоа што е споменат претходно. ${ }^{4}$ Токму затоа (бидејќи функционираат како тема), во

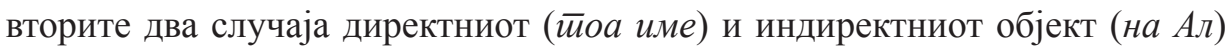
не ја заземаат финалната позиција (т.е. зоната десно од предикатот, која е вообичаена за нив), туку иницијалната (која е својствена за темата).

\footnotetext{
3 Овој пример се разгледува во неинтегрираните иако полупаузата не е сигнализирана со запирка. Во таа смисла, јасно е дека нема целосна сообразеност на пишуваниот со говорениот јазик.

4 Идентификуван е референтот што, преку показателите доставени од зборувачот, адресатот има можност да го посочи со определена именска синтагма, која може да се однесува само на него, т.е. ги исклучува сите други потенцијални референти (сп. Creissels 2006: 129-130).
} 


\section{2 Хиерархија на конструкциите во зависност од (не)идентификуваноста на референтот}

Расположливите примери покажуваат дека конструкциите во врска со директниот и со индиректниот објект ја споделуваат тенденцијата, како и субјектните, да бидат сместени лево од предикатот (во иницијална и во медијална позиција $)^{5}$, а носителот - претставен со референт идентификуван преку претходниот контекст (т.е. во функција на тема). Врз случајот на францускиот јазик, Комбет (Combettes 1998: 33-54) воспоставува хиерархија според која, по субјектот, најконкурентни за носители на неинтегрирана конструкција се директните и индиректните објекти претставени со кратки личнозаменски форми, по кои следуваат другите типови определени именски синтагми (идентификувани референти), а најниско котираат неопределените (неидентификуваните референти), кои се дури и дискутабилни.

Со други зборови, колку е посилна врската помеѓу референтот и претходниот контекст, толку е поверојатна можноста да понесе неинтегрирана конструкција. На пример, најпогоден е исказот во (13), а по него следува варијантата во (13a), каде што референтот (нег̄o г̄o) е, исто така, идентификуван преку тоа што е споменат во претходниот контекст. Варијантата (13б) е пониско во хиерархијата (бидејќи референтите на сопствените именки може, но не мора да бидат споменати претходно), а варијантата (13в) е дури и дискутабилна (бидејќи референтот е неидентификуван, т.е. посочен првпат).

(13) Колку и йомирен, наgежӣа не г̄о найушйаше. (Солев 1998: 50) ('колку и да беше помирен')

(13а) Колку и йомирен, нег̄о наgежӣа не г̄о найушйаше.

(13б) Колку и йомирен, Дано наgежӣа не г̄о найушйаше.

(13в) Колку и йомирен, еgен човек наgежӣа не г̄о найуийаше.

Најпосле, тоа се однесува и на случаите со субјект, во кои конструкцијата во (5) се очекува да биде најчеста (бидејќи е со анафорска заменка), варијантата во (5а) - поретка од неа (бидејќи е со сопствена именка), а варијантата во (5б) - дискутабилна (бидејќи е со неидентификуван референт).

5 Веќе беше посочено дека зоната лево од предикатот е својствена и за (пред сѐ) конструкциите што се однесуваат на субјектот. Освен тоа, таа позиција е карактеристична и за причинските конструкции, а не само за концесивните. 


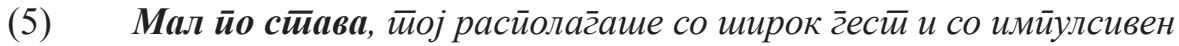
барит̄он. (Конески 1988: 111) ('иако беше мал по става').

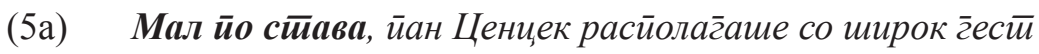
и со имйулсивен барийон.

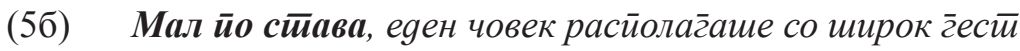
и со имйулсивен барийон.

Разгледувајќи ги случаите со субјект (во францускиот јазик), тенденцијата иницијалните неинтегрирани конструкции да се однесуваат на идентификуван референт ја посочува Неве (Neveu 1998:185-186). Во согласност со тоа, во ниту еден од случаите во функција на субјект не е неидентификуван референт. Во седум случаи е експлицитно анафорски, т.е. претставен со заменката $\bar{u} о j / \bar{u} a a / \bar{u} о a(17)$, а во шест не е изразен (18), што, исто така, значи дека е анафорски, односно дека сеподразбира одпретходниот контекст. $^{6}$ Во таа смисла, во случаите со неизразен (имплицитен) субјект, тој се подразбира од претходниот контекст до толкава мера што и не мора да се изрази. Според тоа, во нив неговата врска со претходниот контекст е посилна дури и одошто во случаите со анафорска заменка.

(17) Иако најмал, йој веќе оgамна не беше мал. (Солев 1998: 12) ('иако беше најмал').

(18) Собрани на умирачка, веќе заборавиле на умрениой иживи со живи, умрени со умрени - зборуваай за койчейо ийо се скинало, за йлайайа шӣо заgочнила (...) (Солев 1998: 81) 'иако се собрани на умирачка').

Во другите (девет) случаи е претставен со определени именски синтагми

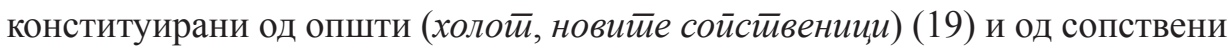
именки (Марија, Дано...) (20).

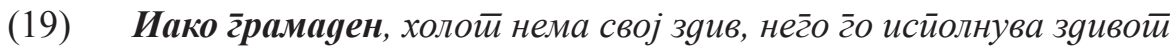

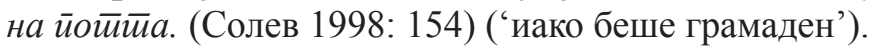

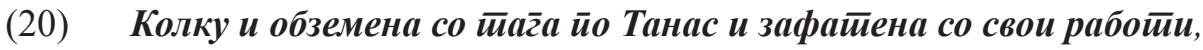

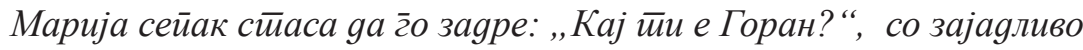

\footnotetext{
6 Во случаите со неизразен (имплицитен) субјект, тој се подразбира од претходниот контекст до толкава мера што и не мора да се изрази. Според тоа, во нив неговата врска со претходниот контекст е посилна дури и одошто во случаите со анафорска заменка.
} 


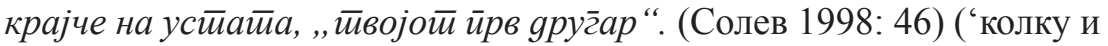
да беше обземена со тага по Танас и зафатена со свои работи').

Тоа е универзална карактеристика на неинтегрираните конструкции, т.е. не е ексклузивна за концесивните. Станува збор за сразмерност помеѓу информацискиот статус на конструкциите, од една страна, и на нивните носители, од друга. Во тој поглед, неинтегрираните конструкции се, како што беше посочено, информациски секундарни, и тоа мошне често затоа што нивната содржина е директно посочена или антиципирана во претходниот контекст. Според тоа, очекувано е што тие содржини најчесто се припишуваат на идентификувани референти, кои, исто така, најчесто се анафорски, споменати во претходниот контекст. Затоа, исказот во (21), каде што и содржината на неинтегрираната конструкција (несигуурен) и нејзиниот носител $(\bar{u} о j)$ се изведени од претходниот контекст, е повообичаен од исказот во (22), каде што носителот (еgен човек) се посочува првпат.

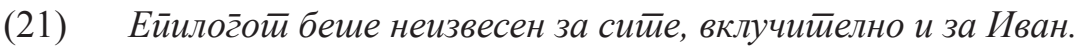

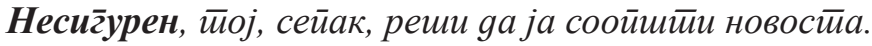

(22) Ейилог̄ой беше неизвесен за ситее, вклучително и за Иван. Несигуурен, еден човек, сейак, реши gа ја соойшӣи новосӣа.

Изложеното може да се сумира во следниве точки:

- бидејќи често се надоврзуваат на (или, во некои случаи, дури и го повторуваат) претходниот контекст, во повеќето случаи конструкциите ја заземаат иницијалната позиција;

- најчесто се сврзуваат со субјектот затоа што тој се надоврзува на (е споменат во) претходниот контекст почесто од референтите во другите синтаксички функции;

- најпосле, конструкциите се информациски секундарни дури и во случаите каде што нивната содржина не е спомената во претходниот контекст, едноставно затоа што авторот решава да ги претстави како комуникациски помалку динамични во однос на другиот дел од исказот (информациското јадро). 


\section{3 Морфолошкиот аспект и семантичките разлики помеѓу конструкциите}

\section{1 Конструкции конституирани од (глаголски и квалификативни) придавки, глаголски прилози и именки}

Конструкциите најчесто се конституирани од глаголски придавки, кои се јавуваат во следниве 13 случаи: (6), (7), (8), (11), (12), (13), (15), (18), (20), (23)-(26)

(6) Секог̄аш воздржан со своийе gеца, ни gа г̄и гали ни gа г̄и йейа, ни gа г̄и фали ни gа г̄и куgи, йој не криеше дека најг̄олема наgеж йолаг̄а йокму во нег̄о. (Солев 1998: 39) ('иако секогаш беше воздржан со своите деца')

(7) А неизвесностйа, колку и ойег̄найа, сѐ йовеке му йежеше (...) (Солев 1998: 70) ('колку и да беше отегната')

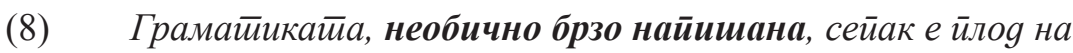

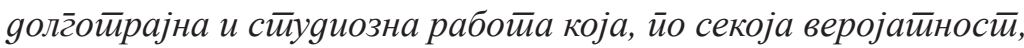

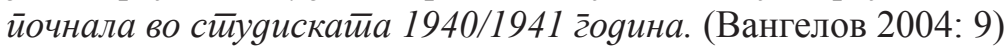
('иако е необично брзо напишана')

(11) Тог̄аш оgеше речиси секој gен на факулиеети, иако веќ дийломиран и врабойен (...) (Солев 1998: 56)

('иако веќе беше дипломиран и вработен').

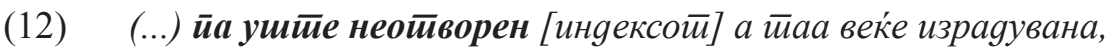
брзаше gа му го йокаже на Танас. (Солев 1998: 30)

('иако сѐ уште не беше отворен')

(13) Колку и йомирен, наgежт̄а не г̄о найушйаме. (Солев 1998: 50) ('колку и да беше помирен')

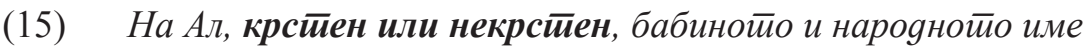
му остиана за век. (Чинго 1989: 13)

('независно од тоа дали беше крстен или некрстен')

(18) Собрани на умирачка, веќе заборавиле на умрениот̄ и-живи со живи, умрени со умрени - зборуваай за койчетио шито

\footnotetext{
7 Во овој дел ќе бидат наведени сите ексцерпирани примери.
} 
се скинало, за йлайайа шӣо заgоцнила (...) (Солев 1998: 81) ('иако се собрани на умирачка')

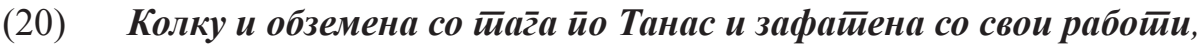

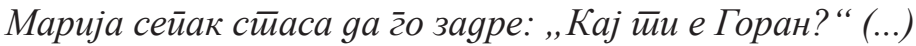
(Солев 1998: 46) ('колку и да беше обземена со тага по Танас и зафатена со свои работи')

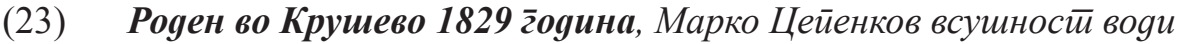
йоиекло оg блискойо gо Прилей село Ореовеи, (йо машка лоза) u оg Крушево (йо женска лоза) (...) (Тодоровски 2007: 163) ('иако е роден во Крушево')

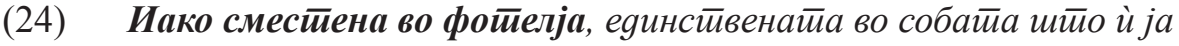

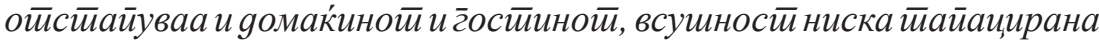

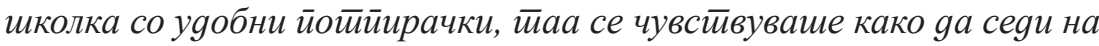
gва стиола (...) (Солев 1998: 60) ('иако беше сместена во фотелја')

(25) Веќе во г̄оgини, йобелен, йој се држи йрав како йушка, како шито е висок и витиок, и само во оуой неусейно ја йовлекува деснайа ног̄a. (Конески 1988: 40) ('иако веќе е побелен')

(26) Така, уииие незакрейнай на факулйейой, ийойуку йушииил корен, йака gа се каже, на рабойнойо местио, Дано се сйакува,

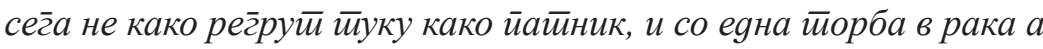
вреќа на рамо г̄о ост̄ави роgниот̄ г̄pag (...) (Солев 1998: 38)

('иако сѐ уште не беше закрепнат на факултетот')

По нив следуваат квалификативните придавки, кои се јавуваат во следниве девет случаи (5), (14), (16), (17), (19), (27)-(30).

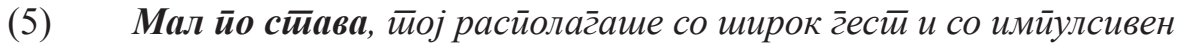
барийон. (Конески 1988: 111) ('иако беше мал по става')

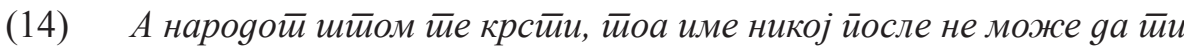
гेо земе, арно или лошо. (Чинго 1989: 13) ('и да е арно и да е лошо' / 'независно од тоа дали е арно или лошо')

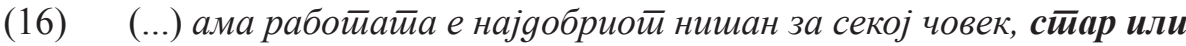
млаg! (Чинго 1989: 83) ('и да е стар и да е млад' / 'независно од тоа дали е стар или млад') 
(17) Иако најмал, йој веќе оgамна не беше мал. (Солев 1998: 12) ('иако беше најмал')

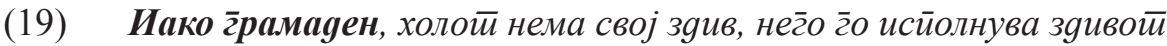
на йой̄̄a. (Солев 1998: 154) ('иако беше грамаден')

(27) Учйив кон йосйарийе, gури и со книг̄a йоg рака, како божем

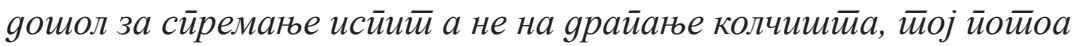
влегууваше во собайа на Дано и веgнаш ја остиаваше книг̄айа на маса а самиой се фрлаше на креветиоти иррво gа гіи искаже

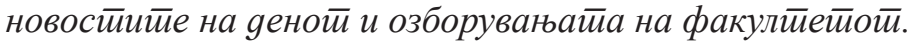

(Солев 1998: 34) ('иако беше учтив кон постарите')

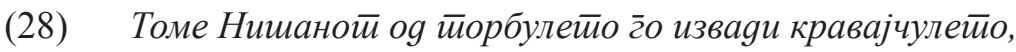
ама не ни йокму кравајче, малку йогоолемо оg ирроскура, нејсе, йакво вакво, кравајче се сметиа. (Чинго 1998: 69) ('и да е такво и да е вакво / независно од тоа дали е такво или вакво')

(29) Но сег̄а морам gа г̄о исйијам нег̄овиой чај. Тој г̄орчи и е невкусен. Мене не іиреба gа ми бияе нишито вкусно. Жежкок и горрилив, чајой ми оgг̄овара. (Бужаровска 2017: 10)

('иако е жежок и горчлив')

(30) Колку и свесен, и сѐ йовеќе свесен за тиаа своја йройивречносй, Дано беше соживеан со неа како со слей јазол и не сакаше на никој начин, а најмалку сиираничен и груб, gа се ослобоgи, а ушиее йомалку некој gруг̄ gа г̄о ослобоgи оg неа. (Солев 1998: 139)

('колку и да беше свесен за таа своја противречност')

Што се однесува на глаголскиот прилог, К. Конески, кој е автор на најподробниот опис на неговите синтаксички и семантички аспекти во македонскиот јазик, одбележува:

Во описите на употребата на глаголскиот прилог во одделните словенски јазици се констатира дека тој може да биде употребен во значење на допусна реченица; меѓутоа, ваквото значење пошироко не може да се потврди. Сепак, во одделни, иако ретки примери (во нашиот материјал сретнавме само два такви), глаголскиот прилог може да има концесивна интерпретација. (Конески 1999: 195)

8 Освен како концесивна, оваа конструкција може да се толкува и како причинска: 'токму затоа што е жежок и горчлив'. 


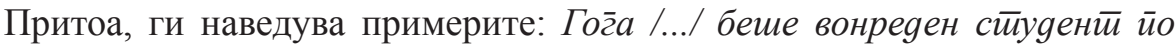

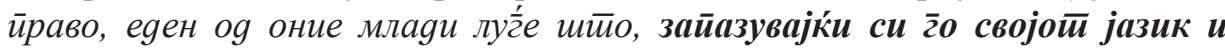

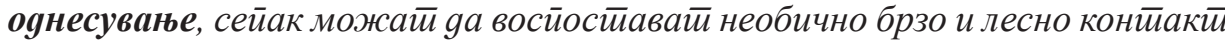

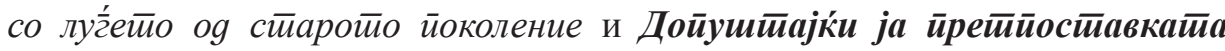

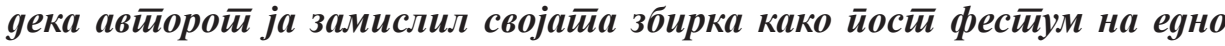

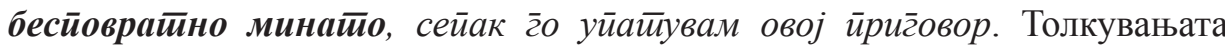
гласат: ‘иако си ги запазуваат својот јазик и однесување' и 'иако ја допуштам претпоставката дека авторот ја замислил својата збирка како постфестум на едно неповратно минато'. Сепак, покрај двата примера, К. Конески (1999) посочува дека концесивна интерпретација може да имаат и некои примери со негирани глаголски прилози, од типот на: И не г̇леgајќи виge geка селанеиой йлаче ('иако не гледаше'); И не сакајќи се йомоли со иееиеелой на својой изгаснай жар за уйрешниой gен ('иако не сакаше').

Во материјалот за овој труд се изделуваат три концесивни глаголски прилози (9), (10), (31), од кои сите се негирани.

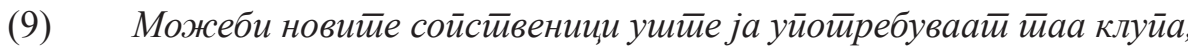
не знаејќи gека е йаа воен йрофеј на баба Дунавка, истио како и оној ирешлен. (Конески 1988: 39) ('иако не знаеја дека таа е воен трофеј на баба Дунавка' / 'без да знаат дека таа е воен трофеј на баба Дунавка')

(10) Сег̄a и мојой син краgе, си реков и се насолзив, не сакајќи gа йлачам йpeg Генчо. (Бужаровска 2017: 44) ('иако не сакав да плачам пред Генчо' / ‘без да сакам да плачам пред Генчо')

(31) Не ирризнавајќи дека му е сиирав, сейак ја беше олабавил

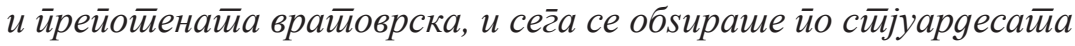
gа му gонесе виски. (Солев 1998: 155) ('иако не признаваше дека му е страв' / ‘без да признае дека му е страв')

Именските конструкции се јавуваат само во два случаја (32), (33).

(32) (...) иако браќа, ииие беа йолку различни, шимо рейко се сог̄ласуваа и йо најиростии ирамаға; (Солев 1998: 86) ('иако беа браќа')

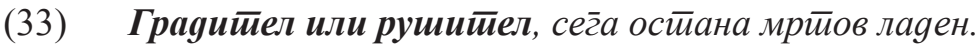
(Солев 1998: 144) ('независно од тоа дали е градител или рушител’) 


\section{2 Лексички конкретизатори и семантички разлики}

Во три од претходните примери, во примарната предикација се јавува партикулата сейак, која го уточнува допусното значење (8), (20), (31).

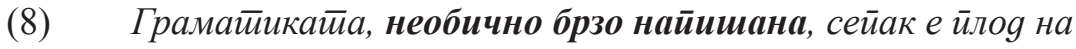

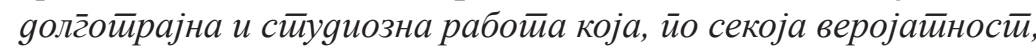
йочнала во сииудискайа 1940/1941 гооина. (Вангелов 2004: 9)

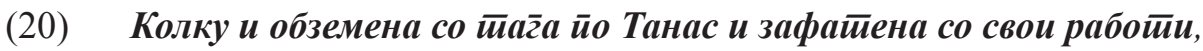
Марија сейак сйаса gа г̃o заgре: „Кај йи е Горан?“

(...) (Солев 1998: 46)

(31) Не йризнавајќ́ дека му е сиирав, сейак ја беше олабавил и йрейоиенайа врайоврска, и сег̄а се облираме йо сиијуарgесайа gа му донесе виски. (Солев 1998: 155)

Како алтернатива на партикулата сейак (во трите случаи), во четири од претходните примери функционира сврзникот иако, кој ги воведува конструкциите: иако сместенен во фот̄елја, иако веќе gийломиран и врабойен, иако најмал, иако брака. ${ }^{9}$

Најпосле, се наметнува едно согледување во врска со семантичкиот аспект. Примерите покажуваат дека неинтегрираните конструкции можат да ги изразат и фактивната и нефактивната концесија. Во таа смисла, првата е соодветна на иако-, а втората на $u g a$-допусните реченици. ${ }^{10}$ Како што се согледува од парафразите покрај примерите, почесто - во 15 случаи, е во прашање фактивната: ‘иако веќе беше дипломиран и вработен', 'иако беше мал по става' итн. Нефактивната се јавува: во девет случаи од типот на 'колку и да беше помирен', 'и да е арно и да е лошо' / 'независно од тоа дали е арно или лошо'; во три случаи со негација, од типот на 'иако не признаваше дека му е страв' / 'без да признае дека му е страв'.

\section{4 Заклучни согледувања}

Освен релативно флексибилната линеаризација, карактеристиката на секундарни предикати и релацијата со елемент на примарната предикација,

9 Што се однесува на ситуацијата во францускиот јазик, Комбет (Combettes 1998: 52) посочува дека лексичките уточнувања (со quoique, bien que, même) се многу чести. Во таа смисла, концесијата не е секогаш доволно изразена, па во некои контексти, ако се изостават, може да се остави простор и за други толкувања (на пример, причинско).

10 За разликата меѓу иако- и и ga-допусните реченици в. Минова-Ѓууркова (2000: 288-290). 
концесивните неинтегрирани конструкции ја споделуваат и општата информациска карактеристика на неинтегрираните конструкции. Во тој поглед, тие се информациски секундарни, т.е. не влегуваат во информациското јадро на исказот, па не може да се разгледуваат ни како тема ни како рема во вистинска смисла, туку само како секундарна тема (ако е содржината спомената во претходниот контекст) или како секундарна рема (ако содржината се посочува првпат).

Во таа смисла, тие се оценети од авторот како информациски секундарни дури и во случаите каде што функционираат како секундарна рема (т.е. каде што не се ни споменати ни антиципирани во претходниот контекст), па очекувано е што најчесто - во 19 случаи, ја заземаат иницијалната позиција, која е својствена за елементи со низок степен на комуникациски динамизам. Покрај нив, се изделуваат пет случаи со финална позиција и три со медијална. Во согласност со тоа што, директно или индиректно, конструкциите најчесто се надоврзуваат на претходниот контекст, нивни носители во сите случаи се идентификувани референти (определени именски синтагми), кои се, исто така, споменати претходно.

На синтаксички план, во повеќето случаи - 22, носител на конструкциите е субјектот, што е во согласност со тоа што е (освен почест воопшто), како и содржината на конструкциите, споменат во претходниот контекст (и, според тоа, функционира како тема) почесто од референтите во другите синтаксички функции. Покрај нив, се јавуваат три случаи со директен објект, еден со индиректен и еден со постмодификатор.

Од морфолошки аспект, преовладуваат случаите со глаголски придавки, кои се јавуваат 13 пати. По нив следуваат квалификативните придавки, кои се застапени во девет случаи. Маргинално се јавуваат глаголските прилози - во три случаи, и именките - во два.

Во некои случаи како лексички конкретизатори на концесијата функционираат партикулата сейак и сврзникот иако. Што се однесува на семантичкиот аспект, примерите покажуваат дека конструкциите, како и сложените реченици, можат да ги изразат и фактивната и нефактивната концесија.

\section{Библиографија}

Бужаровска, Р. (2017). Мојот̄ маж. Скопје: Или-Или.

Вангелов, А. (2004). Конески и Јакобсон. Скопје: Фондација за македонски јазик Небрегово.

Геговски, Д. (1996). Допусносложените реченици во македонскиот и во полскиот јазик. Макеgонски јазик XLV-XLVII: 317-331. 
Конески, Б. (1988). Дневник ӣо мног̄у г̄oguни. Скопје: Македонска книга.

Конески, К. (1999). За макеgонскиой гллагол. Скопје: Детска радост.

Минова-Ѓуркова, Л. (2000). Синйакса на макеgонскиой сйанgарgен јазик. Скопје: Магор.

Солев, Д. (1998) Мриива ишрка. Скопје: Култура.

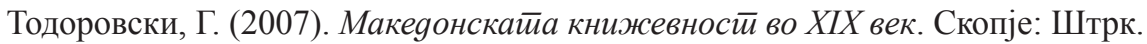

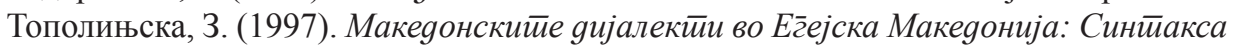
(ī. 2). Скопје: МАНУ.

Цветковски, Ж. (1982). Дойуснит̄е реченици во макеgонскиой јазик. Магистерски труд. Скопје: Универзитет „Св. Кирил и Методиј“.

Чинго, Ж. (1989). Ал. Скопје: Македонска книга.

Шокларова-Љоровска, Г. (1996). Дойуснит̄е реченици во макеgонскиой и во иолскиой јазик. Во М. Каранфиловски (уред.). XXII научна gискусија на XXVIII мег̌уунароgен семинар за макеgонски јазик, литерайура и кулӣура, 195-202. Скопје: УКИМ.

Combettes, B. (1998). Les constructions détachées en français. Paris: Édition Ophrys.

Creissels, D. (2006). Syntaxe générale une introduction typologique 1 (catégories et constructions). Paris: Hermes Science Publications.

Firbas, J. (1992). Functional sentence perspective in written and spoken communication. Cambridge: Cambridge University Press.

Morel, M.A. (1996). La concession en français. Paris: Édition Ophrys.

Neveu, F. (1998). Études sur l'apposition ; Aspects du détachement nominal et adjectval en français contemporain, dans un corpus de textes de J.-P. Sartre. Paris: Honoré Champion Editeur.

Noailly, M. (1999). L'adjectif en français. Paris: Édition Ophrys. 